\title{
SPECTROPHOTOMETRY OF FAIRLEY'S NEW BLOOD PIGMENT, METHEMALBUMIN
}

\author{
BY CHARLES L. FOX, JR. ${ }^{1}$ \\ (From the Department of Bacteriology, College of Physicians and Surgeons, Columbia \\ University, New York City)
}

(Received for publication April 16, 1941)

In the course of the study of acute hemolytic anemia and hemoglobinuria during administration of sulfonamide drugs (1), the patients' sera were found to contain a pigment which, like methemoglobin and sulfhemoglobin, showed an absorption in the red region of the spectrum. The characteristic band of this pigment, around $\lambda 620 \mathrm{~m} \mu$ and adjacent to that of methemoglobin, was not altered by cyanide, although that of methemoglobin was obliterated. Furthermore, comparisons with known mixtures and calculations based upon absorption coefficients for sulfhemoglobin, methemoglobin, and hemoglobin did not correspond with the observed spectrophotometric measurements. ${ }^{2}$

At this time (1940) Fairley's paper appeared describing a new pigment (3) with practically identical properties named methemalbumin (1937, 1938) (4). The pigment, which did not occur in washed, laked erythrocytes nor in urine, was readily formed by incubating laked human erythrocytes with human plasma at $37^{\circ} \mathrm{C}$. for several days. Our observations were in accord with these.

Inasmuch as the sera in cases of acute hemolytic anemia contained hemoglobin, methemoglobin, and apparently methemalbumin (1), it was necessary to obtain absorption coefficients for this new pigment in order to determine its proportion in these sera. Fairley's procedure was, therefore, repeated and the resulting solutions (after centrifuging off the heavy precipitate to be described after further study) were analyzed with the Hardy recording spectrophotometer (5).

To establish the identity of the new pigment, two reagents were used: 5 per cent neutralized $\mathrm{NaCN}^{3}$ and 3 per cent hydrogen peroxide. The cyanide was used first to obliterate the absorption

\footnotetext{
1 Aided in part by the Dazian Foundation.
}

2 Absorption coefficients for hemoglobin and methemoglobin taken from Fox and Cline (7) and for sulfhemoglobin taken from Drabkin (2).

3 Ammonium sulfide may be used but this frequently causes confusion by subsequently producing sulfhemoglobin. caused by methemoglobin at $\lambda 630 \mathrm{~m} \mu$ without changing absorption in this region attributed to methemalbumin. Hydrogen peroxide was next added to obliterate the absorption band of sulfhemoglobin, if present.

In Figure 1 are shown the transmission curves of the new pigment, methemalbumin, together with curves of methemoglobin, sulfhemoglobin, and oxyhemoglobin and the changes that negate the absorption in the region of interest. ${ }^{4}$ In the case of methemalbumin after the addition of cyanide, the absorption in the red region is decreased slightly owing to the removal of small contaminating amounts of methemoglobin. The subsequent addition of hydrogen peroxide caused no further change. Table I summarizes these findings which correspond to Fairley's results.

TABLE I

Differential reactions of the blood pigments

\begin{tabular}{c|c|c|c}
\hline \hline Reagent* & $\begin{array}{c}\text { Methemo- } \\
\text { globin } \\
\lambda 630 \mathrm{~m} \mu \\
\text { band }\end{array}$ & $\begin{array}{c}\text { Sulfhemo- } \\
\text { globin } \\
\lambda 620 \mathrm{~m} \mu \\
\text { band }\end{array}$ & $\begin{array}{c}\text { Methem- } \\
\text { albumin } \\
\lambda 620+\mathrm{m} \mu \\
\text { band }\end{array}$ \\
\hline $\begin{array}{c}\text { Cyanide, } 5 \text { per cent . } \\
\mathrm{H}_{2} \mathrm{O}_{2}, 3 \text { per cent... }\end{array}$ & $\begin{array}{c}\text { obliterated } \\
\text { obliterated }\end{array}$ & $\begin{array}{l}\text { unaltered } \\
\text { obliterated }\end{array}$ & $\begin{array}{c}\text { unaltered } \\
\text { unaltered }\end{array}$ \\
\hline
\end{tabular}

* Fairley also used several other reagents which disperse the band of methemoglobin but not the adjacent band of methemalbumin $(3,4)$. Ammonium sulfide caused confusion by subsequently producing a sulfhemoglobin band at $620 \mathrm{~m} \mu$. Stokes' reagent, hydrazine hydrate and sodium fluoride might also be used but the results with cyanide alone are quite convincing. The major problem is differentiation from sulfhemoglobin; $\mathrm{H}_{2} \mathrm{O}_{2}$ is the only reagent known to disperse the sulfhemoglobin band but not the methemalbumin band. This test also excludes verdehemochromogens (8).

\section{Determination of absorption coefficients}

In Figure 2 is shown the transmission curve $A$ of the supernatant of a plasma hemoglobin solu-

4 For ease of comparison arbitrary concentrations have been selected. Before spectroscopy, all specimens were diluted about 10 times with $\mathrm{M} / 4$ phosphate buffer of $\mathrm{pH}$ 7.0 to prevent variations in the absorption by methemoglobin with varying $\mathrm{pH}(2)$. 


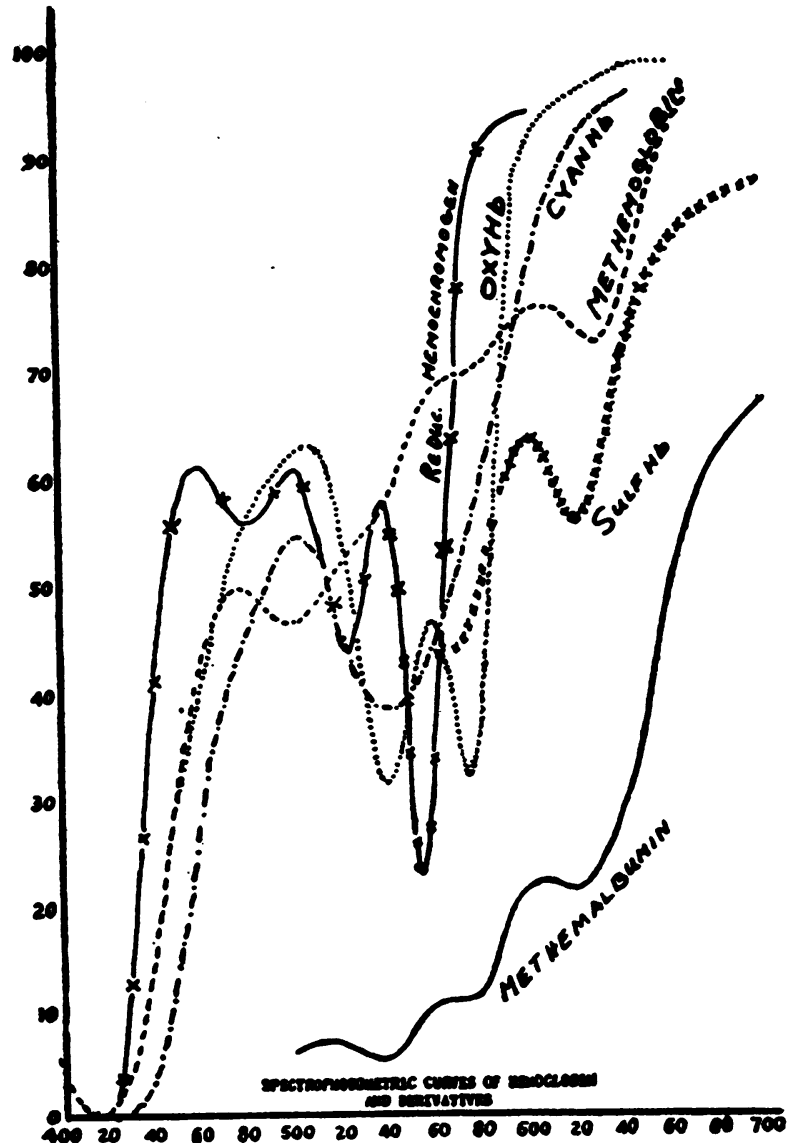

Fig. 1

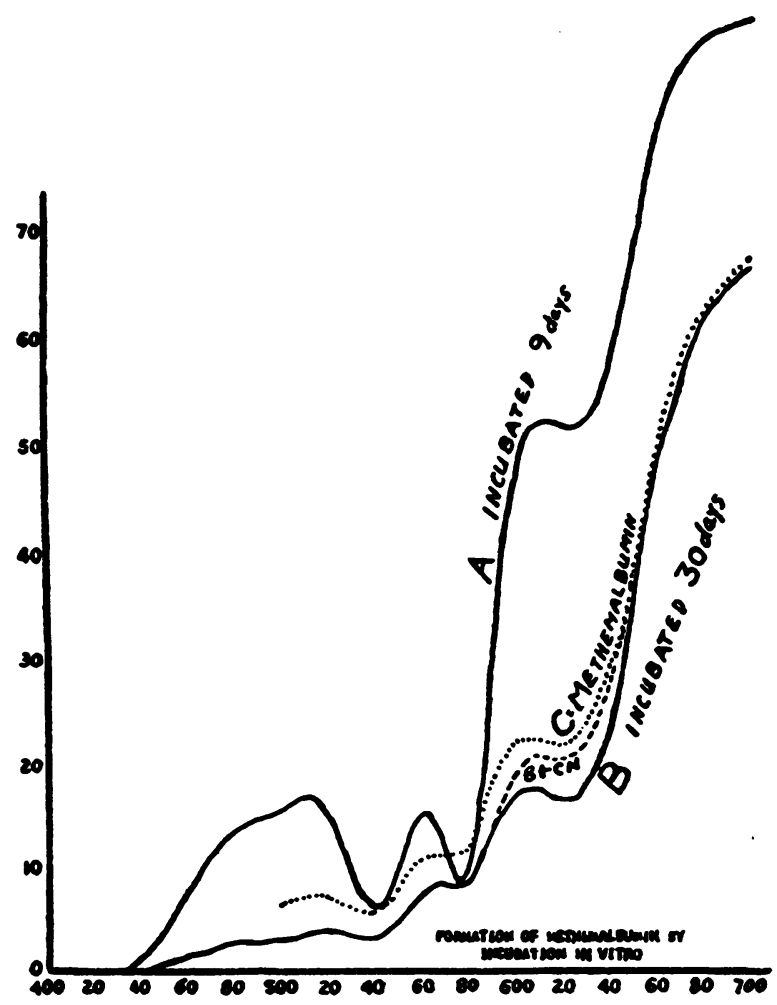

FIG. 2

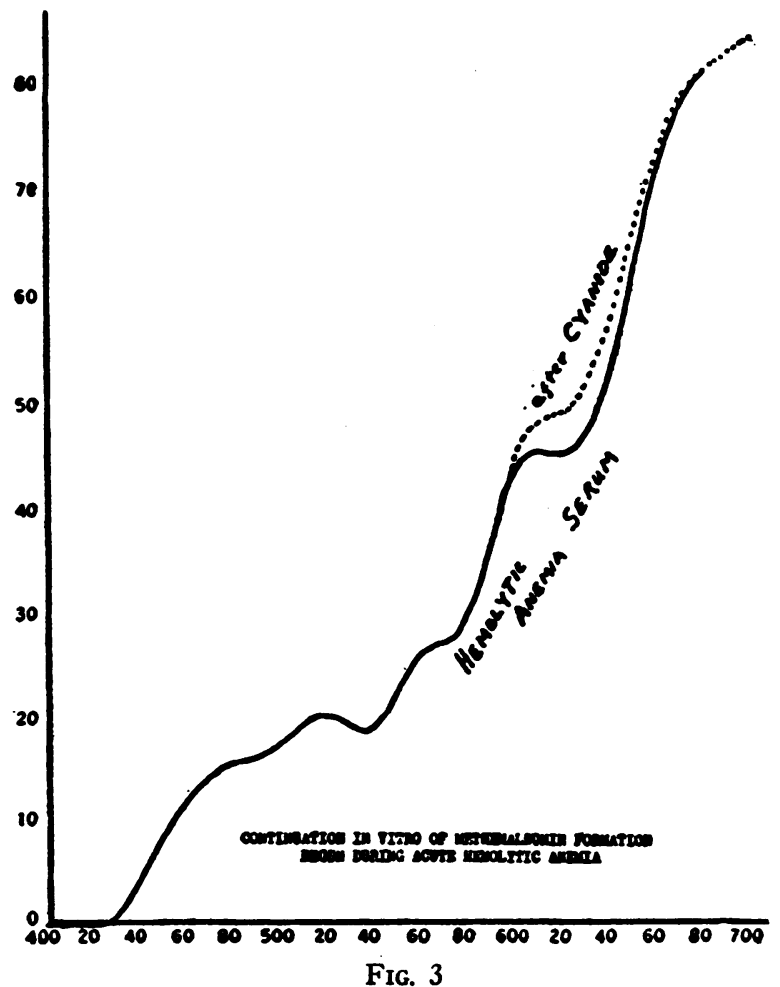


tion that had not been incubated as long as the solution represented in curve $B$. The hemoglobin bands present in curve $A$ had practically disappeared in curve $B$, indicating almost complete disappearance of hemoglobin from the solution. It was then assumed that the curve $B$ represented only methemalbumin and methemoglobin. The total pigment was determined by iron analysis with alpha alpha' dipyridyl (6). The methemoglobin, determined independently by the change in optical density at $\lambda 630 \mathrm{~m} \mu$ after the addition of cyanide, was then subtracted from the total to obtain the quantity of methemalbumin present. Since the absorption coefficients of methemoglobin had been determined previously on this instrument (7), it was possible to subtract its absorption from curve $B$, using this formula based on Beer's and Bouguer's laws :

$$
\log \frac{1}{T}=k c d
$$

$d=$ thickness of cell in $\mathrm{cm}$.

$c=$ concentration in grams per cent

$k=$ absorption coefficient

$T=$ light transmission, per cent.

The calculations are summarized in Table II and the resulting curve $C$ of methemalbumin is shown in Figure 2. By the same equation, the absorption coefficients for methemalbumin were computed and are listed in Table II.

TABLE II

Computation of absorption coefficients of methemalbumin

\begin{tabular}{c|c|c|c|c}
\hline \hline Wavelength & $\begin{array}{c}\text { Experi- } \\
\text { mental } \\
\text { log 1/T }\end{array}$ & $\begin{array}{c}\text { Methemoglobin } \\
\text { to be } \\
\text { subtracted } \\
\left(0.0572 \times K_{\text {Mhb })}\right.\end{array}$ & $\begin{array}{c}\text { Methem- } \\
\text { albumin } \\
\text { computed } \\
\text { absorption }\end{array}$ & $\begin{array}{c}\text { Methem- } \\
\text { albumin } \\
\text { aborption } \\
\text { coefficients }\end{array}$ \\
\hline$m \mu$ & & & & \\
700 & 0.177 & 0.007 & 0.170 & 0.72 \\
660 & 0.323 & 0.027 & 0.296 & 1.25 \\
630 & 0.751 & 0.133 & 0.618 & 2.61 \\
620 & 0.788 & 0.125 & 0.663 & 2.79 \\
600 & 0.770 & 0.113 & 0.657 & 2.77 \\
580 & 1.059 & 0.137 & 0.922 & 3.89 \\
560 & 1.112 & 0.144 & 0.968 & 4.08 \\
540 & 1.456 & 0.222 & 1.234 & 5.2 \\
520 & 1.414 & 0.272 & 1.142 & 4.83 \\
500 & 1.502 & 0.319 & 1.183 & 5.0 \\
480 & 1.55 & 0.286 & 1.264 & 5.34 \\
\hline
\end{tabular}

In order to check the accuracy of the data, the resulting absorption coefficients were used to compute the concentrations of hemoglobin, methemoglobin, and methemalbumin in the solution containing all three represented by curve $A$ in Figure 2. The method previously described (7) of solving three simultaneous equations was used. Equations were set up at the peak wavelength of each component $\lambda 540 \mathrm{~m} \mu, \lambda 630 \mathrm{~m} \mu, \lambda 620 \mathrm{~m} \mu$, and solved for the concentration of each component, e.g., at $\lambda 630 \mathrm{~m} \mu$.

$$
\begin{aligned}
& \log \frac{1}{T}= 0.133 \times \text { concentration } \mathrm{Hb} .+2.32 \\
& \times \text { concentration } \mathrm{MHb} .+2.55 \\
& \text { concentration MHAlb. }
\end{aligned}
$$

As a check on the reliability of the entire computation, the values for the concentration of each component were then substituted at 6 other wavelengths and values for the transmission of such a solution were computed. Comparison with the observed values are shown in Table III and serve to establish the relative accuracy of the coefficients of methemalbumin that were obtained.

The absorption coefficients are quite similar to those for methemoglobin and further confirm Fairley's suggestion that "the iron is held in the trivalent state, and is even more resistant to reducing agents than methemoglobin itself" (4).

It was also possible to apply these data to serum obtained from a patient who had suffered acute blood destruction during therapy with sulfonamide drugs (1). This specimen had been measured with the Hardy at the time of the hemolytic crisis. ${ }^{5}$ It was then allowed to remain in the refrigerator for 2 months and again measured (Figure 3 ). The sharp hemoglobin bands originally present had almost entirely disappeared and the band in the red region that resisted both cyanide and hydrogen peroxide had increased markedly; apparently, much more methemalbumin had formed. The methemoglobin was computed by the change in density at $\lambda 630 \mathrm{~m} \mu$ after adding cyanide. The concentrations of hemoglobin and methemalbumin

5 Case 4 in Bibliography (1). 
TABLE III

Check on absorption coefficients of methemalbumin

\begin{tabular}{|c|c|c|c|c|c|}
\hline $\begin{array}{l}\text { Wave- } \\
\text { length }\end{array}$ & $\begin{array}{c}\text { Hemoglobin } \\
\left(0.082 \times k_{\mathrm{Hb}}\right)\end{array}$ & $\begin{array}{l}\text { Methemoglobin } \\
\left(0.04 \times k_{\mathrm{MHb}}\right)\end{array}$ & $\begin{array}{c}\text { Methemalbumin } \\
\left(0.069 \times K_{\text {MHalb. }}\right)\end{array}$ & $\begin{array}{l}\text { Calculated } \\
\log 1 / T\end{array}$ & $\begin{array}{l}\text { Experimental } \\
\log 1 / T\end{array}$ \\
\hline $\begin{array}{l}m \mu \\
600 \\
580 \\
560 \\
520 \\
500 \\
480\end{array}$ & $\begin{array}{c}\text { gram per cent } \\
0.046 \\
0.585 \\
0.476 \\
0.338 \\
0.271 \\
0.340\end{array}$ & $\begin{array}{c}\text { gram per cent } \\
0.078 \\
0.076 \\
0.101 \\
0.19 \\
0.223 \\
0.200\end{array}$ & $\begin{array}{c}\text { gram per cent } \\
0.191 \\
0.27 \\
0.282 \\
0.333 \\
0.345 \\
0.368\end{array}$ & $\begin{array}{l}0.316 \\
0.951 \\
0.859 \\
0.861 \\
0.839 \\
0.908\end{array}$ & $\begin{array}{l}0.312 \\
0.969 \\
0.824 \\
0.824 \\
0.817 \\
0.88\end{array}$ \\
\hline
\end{tabular}

were computed by two equations ${ }^{\circ}$ at $\lambda 620 \mathrm{~m} \mu$ and $\lambda 540 \mathrm{~m} \mu$. Using the concentrations obtained, values for $\log 1 / T$ at 8 other wavelengths were computed and are compared with the experimental values (Table IV).

TABLE IV

Formation of methemalbumin at $10^{\circ} \mathrm{C}$. after intravascular hemolysis

\begin{tabular}{ccc}
\hline \hline Wavelength & $\begin{array}{c}\text { Experimental } \\
\log 1 / T\end{array}$ & $\begin{array}{c}\text { Calculated } \\
\log 1 / T\end{array}$ \\
\hline$m \mu$ & & \\
700 & 0.077 & 0.078 \\
660 & 0.140 & 0.142 \\
630 & 0.328 & 0.329 \\
620 & 0.344 & 0.344 \\
600 & 0.359 & 0.342 \\
580 & 0.538 & 0.544 \\
560 & 0.594 & 0.552 \\
540 & 0.727 & 0.727 \\
520 & 0.699 & 0.665 \\
500 & 0.770 & 0.752 \\
480 & 0.809 & 0.724 \\
\hline
\end{tabular}

Values calculated on basis of:

Hemoglobin $=0.01144$ gram per cent.

Methemoglobin $=0.0244$ gram per cent .

Methemalbumin $=0.1036$ gram per cent.

There are some discrepancies between Table III and Table IV; it is recognized that the values for the absorption coefficients in the green are the least reliable and the discrepancies are most

6 In view of the fact that the method of simultaneous equations is open to criticism when more than two pigments are present, the concentration of methemalbumin was also calculated more directly by using the residual absorption at $\lambda 620 \mathrm{~m} \mu$ after cyanide and the coefficient for methemalbumin 2.79 (Table II). After subtracting for the absorption of cyanmethemoglobin, the concentration of methemalbumin found is 0.108 gram per cent. This is 4 per cent more than the result 0.104 gram per cent by the method of simultaneous equations. The difference is presumably due to the fact that, in the residual absorption method, no allowance can be made for the small amount of absorption at this wavelength from the hemoglobin present. marked in this region. Furthermore, the serum used in Table IV was that of a case of acute hemolytic anemia, and did not give an absolutely clear solution for study.

\section{SUMMARY AND CONCLUSIONS}

Fairley's new blood pigment methemalbumin was measured in the visible range with the recording spectrophotometer and preliminary values of its absorption coefficients were obtained.

The characteristic absorption curve of this new pigment is compared with that of hemoglobin, methemoglobin, and sulfhemoglobin.

The data obtained are utilized in measuring the formation of methemalbumin, in vivo and in vitro.

\section{BIBLIOGRAPHY}

1. Fox, C. L., Jr., and Ottenberg, R., Acute hemolytic anemia from the sulfonamides. J. Clin. Invest., 1941, 20, 593.

2a. Drabkin, D. L., and Austin, J. H., Spectrophotometric studies. II. Preparations from washed blood cells; nitric oxide hemoglobin and sulfhemoglobin. J. Biol. Chem., 1935, 112, 51.

b. Austin, J. H., and Drabkin, D. L., Spectrophotometric studies. III. Methemoglobin, ibid., 67.

3. Fairley, N. H., The spontaneous disintegration of certain blood pigments, with special reference to methaemalbumin formation. Brit. J. Exper. Path., 1940, 21, 231.

4a. Fairley, N. H., A new blood pigment: pseudo-methaemoglobin. Nature, 1937, 139, 588.

b. Fairley, N. H., Methaemalbumin (pseudo-methaemoglobin). Ibid., 1938, 142, 1156.

5. Hardy, A. C., A new recording spectrophotometer. J. Optic. Soc. America, 1935, 25, 305.

6. Coombs, H. I., Studies of the haemoglobin and iron of the blood. I. The determination of the total iron of blood. Biochem. J., 1936, 30, 1588.

7. Fox, C. L., Jr., and Cline, J. E., The occurrence of methemoglobinemia during sulfanilamide therapy. J. Clin. Invest., 1940, 19, 123.

8. Lemberg, R., Transformation of haemins into bile pigments. Biochem. J., 1935, 29, 1322. 